\title{
Erratum to: Simple technique for RNA purification from mouse inner ear hair cells
}

\author{
Marcin Szaumkessel • Damian Brauze • \\ Małgorzata Rydzanicz • Michał Karlik • \\ Krzysztof Szyfter · Witold Szyfter · Maciej Wróbel
}

Published online: 24 February 2012

(C) Springer Science+Business Media B.V. 2012

\section{Erratum to: Mol Biol Rep}

DOI 10.1007/s11033-012-1465-7

In the original article, the last author's family name was wrongly indicated. It appears correct in this erratum.

The online version of the original article can be found under doi:10.1007/s11033-012-1465-7.

M. Szaumkessel $(\bowtie) \cdot D$. Brauze $\cdot$ M. Rydzanicz $\cdot$ K. Szyfter Institute of Human Genetics, Polish Academy of Sciences, ul. Strzeszynska 32, 60-479 Poznan, Poland

e-mail: marcinsz@man.poznan.pl

M. Karlik · K. Szyfter · W. Szyfter · M. Wróbel

Department of Otolaryngology, Poznan University of Medical

Sciences, Poznan, Poland

e-mail: wrobmac@ump.edu.pl 